Part $V$ is devoted to a discussion of the theoretical and experimental mixture proportioning characteristics of carburetors as applied to aircraft service, also of the mixture ratios for optimum engine performance. The altitude and throttle compensation characteristics experimentally determined for five carburetors are studied and a new type is shown which possesses nearly complete altimetric compensation. The concluding part of the pamphlet discusses means for securing correct altimetric and throttle compensation. Copies of this Bulletin may be obtained from the Committee.

\title{
PUBLICATIONS RECEIVED.
}

Robison's Manual of Radio Telegraphy and Telephony for the Use of Naval Electricians, by Captain S. S. Robison, U. S. Navy; revised by Captain D. W. Todd, U. S. Navy, and Commander S. C. Hooper, U. S. Navy. 5th edition, revised. 307 pages, illustrations, plates, diagrams, 8vo. Annapolis, Maryland, United States Naval Institute, I9r9. Price, \$1.50.

Notions Fondamentales de Chimie Organique, par Charles Moureu. 6me edition, revue et considérablement augmentee. 552 pages, 8vo. Paris. Gauthiers-Villars et Cie, 1919. Price, 24 francs.

The Petroleum Handbook, by Stephen O. Andros. 206 pages, illustrations, I6mo. Chicago, Shaw Publishing Company, 1919. Price, \$2.00.

U. S. Bureau of Mines: Bulletin I8I, Law Serial 19. Abstract of current decisions on mines and mining reported from January to May, I9I9, by J. W. Thompson. 175 pages, 8 vo. Technical paper $21 \mathrm{I}$, approximate quantitative microscopy of pulverized ores, by Will H. Coghill and J. P. Bonardi. 20 pages illustrations, plates, 8 vo. Washington, Government Printing Office, 1919.

Statement of Mr. S. A. Thompson, Secretary and Treasurer, National Rivers and Harbors Congress, Washington, D. C. Extracts from hearings before the Committee on Interstate and Foreign Commerce of the House of Representatives, 66th Congress, first session on H. R. 4378. I6 pages, 8vo. Washington, Govcrnment Printing Office, I919.

Patent Policy of a Public Laboratory, by William D. Shoemaker. Reprinted from the Journal of the Patent Office Society for November, Igrg. I6 pages, 8vo. Washington, Igrg.

Carbo-Coal. Anon. (Steam, vol. xxiii, No. 3, p. 62, September, I919.) - By a new process of low temperature distillation, bituminous coal is treated in such a manner as to recover great quantities of valuable by-products, such as toluol, sulphate of ammonia and valuable oils. From the residue is made a valuable smokeless fuel, of the form of briquettes. Tests of "Carbo-coal" by the Navy disclose that it contains less than 4 per cent. volatile matter, rendering it practically smokeless. Moreover, it is found to work satisfactorily where there is limited grate area and restricted boiler capacity. 